\title{
Discourses of Anti-corruption in Mexico: Culture of Corruption or Corruption of Culture?
}

\author{
Gabriela Coronado, University of Western Sydney ${ }^{1}$
}

\section{Introduction}

Excessive and costly bureaucratic procedures and shrinking economic and social policies have restricted options for Mexican society to function effectively. In order to achieve outcomes demanded by organisations or to fulfil their duties as citizens, Mexicans must operate in the informal polity, outside or against frameworks of regulations. In the context of growing transnational activities the increasing role of unregulated activities is perceived as a large problem, producing loss of control and even criminality that must be eradicated. Mexican people are caught between a battle for economic survival and the burden of a dysfunctional government bureaucracy, the legacy of modernisation and economic rationalism. In that context the use of informal practices is perceived as an easier, or often the only way, to make things happen.

Citizens have to fulfil their rights and responsibilities in the interface between government and the public, in a system characterised by undemocratic practices and abuses of power at all levels. These circumstances have led to an increase of unregulated activities, and boosted the informal sector and the informal polity associated with it. In order to function and fulfil their obligations in such a constrained environment, Mexican citizens and organisations must find alternative strategies.

\footnotetext{
${ }^{1}$ An earlier and preliminary version of this paper was presented in the AILASA conference in Sydney, Australia, 27-29 September 2006. 
The informal polity contains a range of informal practices used to deal with limitations of the formal system and its excessive regulations, what I call 'doing it a la mexicana.' Informal practices include favores (favours), palancas (levers, a little help from insiders or powerful supporters), deploying social reciprocity and family networks, using coyotes (persons paid to do administrative procedures on others' behalf, mostly through personal contacts inside the organisation), giving regalos (gifts) and paying mordidas (bribes). In a developing nation in a Neoliberal world these informal practices become survival strategies, alternative ways for people to deal with administrative procedures that are rigid, inefficient and expensive.

The informal polity is often labelled corruption, but this is problematic. Practices vary and can be considered legitimate or illegitimate from different perspectives. Some can be interpreted as sources of unfair competition, as discriminatory practices or plain corruption, while others demonstrate creativity, innovation or merely a struggle to survive. Individuals dealing with civic duties or working on behalf of organizations interacting with officials claim the processes are dysfunctional, forcing them to use any strategy to get by. Some such strategies can be considered corruption, but others not.

Judgements of these practices are influenced by ideological and political discourses from other cultures, organised around a distinction between developed and developing countries. Such a division and the ideologies that legitimise it dominate the political and economic international contexts in which businesses operate. Countries are evaluated through global instruments defined by views and values from powerful economic players, developed countries and their corporations. Developing countries, such as Mexico, are under their scrutiny, and must regulate their internal affairs following guidelines defined by lender or aid institutions (like the World Bank or International Monetary Fund) that serve the interests of countries and corporations who benefit from the economic performance of aid recipients.

A condition for support is that countries should undertake Neoliberal reforms: lower tariffs, privatise public companies, reduce taxes to attract investment, spend public funds for modernisation not social welfare (Woodward 2005). For countries to be competitive in the global market they need to be (or at least look) attractive (Porter 2001), with low risk, and low levels of corruption. 
These pressures create contradictory demands for developing countries such as Mexico. Corruption in contemporary Mexico exists and can be found at all levels of social, political and economic life. Corrupt governments have accumulated huge fortunes from public resources, and individuals engage in more or less serious acts of corruption in their everyday life (Morris 1991). But governments have to control the growing informal or underground economy and its associated informal practices, in conditions of underdevelopment and reductions in the already inadequate welfare support, where there is no alternative to offer (Theobald 1990). For people to cope under these conditions means to find their own ways, through common informal practices.

Informal practices in earlier times were socially acceptable (e.g. local officials in colonial times personally charged for services to complement their low salary (Lomnitz 2000) but these are now perceived as corruption, and government and society are urged to eradicate them. It is important to recognise, also, that eradicating corruption in developing nations does not necessary serve the interests of all players. As has been noted in the literature on corruption and development (e.g. Robinson 1998) some practices identified as corruption may be advantageous for global business operations, providing economic activities otherwise not available or serving as the 'grease' that dysfunctional bureaucratic organisations need to deliver. Even if such views are contentious they highlight ambiguities and contradictions underlying anti-corruption initiatives.

My purpose here is modest. I focus on issues associated with informal practices that can be seen as survival strategies but are judged as the culture of corruption. I will draw attention to implications of discursive practices that represent and define corruption, pointing to the ideological constructions that help to mask the problem, blaming practices as causes instead of recognising them as effects of larger historically rooted political and economic interests. I also explore some implications of metaphoric language used in the Mexican public discourse about corruption that connect corruption to cultural values.

In this framework I consider the implicit postcolonial ideology through which countries and their cultures are understood in global exchanges, influencing the way corruption and country attractiveness are measured. To highlight the impact of postcolonial 
ideologies I briefly refer to two instruments used by global business to measure country risk: Transparency International (TI) Index (www.transparency.org) and Hofstede’s dimensions of national cultures (2001). Then I analyse some examples of anticorruption initiatives in Mexico. In my interpretation I draw on my own experience as a Mexican, and on a research project in Mexico from 2005-2007 on the use of informal practices. $^{2}$ Although in this paper I do not analyse stories collected in the research project, they are implicit in my interpretations of the perspective of ordinary Mexicans.

\section{‘Culture of Corruption’ and Postcolonial Ideology}

I lived in Mexico most of my life, experiencing the difficulties created by dysfunctional bureaucratic systems. I dealt with public offices, always fearing I would be unable to fulfil my needs or duties as a citizen. Every time I asked myself: Do I have enough money to pay the expensive imposts, and more if they ask me for a mordida? Are they going to ask me for another document not mentioned before, making me waste another day? Are they going to send me to another desk after one hour in a queue? Or ask me to come back tomorrow? Many other Mexicans like me have to deal with these concerns every time we pay for services, get driving permits or just drive in the city, or complete the procedures to marry, to register a birth or death. Mexicans confront these difficulties everyday throughout their life. They also embody what is commonly called the problem of corruption, captured in the phrase cultura de la corrupción (culture of corruption).

The association of corruption with culture in this phrase implies that Mexican culture (like that of any comparable nation) is characterized by corruption that seems to derive from tradition through our socialization, inherited from our ancestors. It implies we have been 'imprinted' by corruption in the way we behave. It highlights also a core problem for global business. Culture and corruption seem to come together as a problem for global agents, unsure of how to treat potential business partners, and reduce the risk they will spoil 'good' business. Even though there is often a reluctance on the part of theorists to link corruption with culture, some writers from a business perspective make this link overt, as for example, Davis and Ruhe (2003) who correlate the TI corruption index and Hofstede’s cultural dimensions in country assessments.

\footnotetext{
2 This project is part of a comparative project on informal practices, Cross-cultural 'larrikins' in a Neoliberal world: ideology and myth in postmodern Australia, Mexico and Brazil, with the participation of Prof Bob Hodge, Dr. Gabriela Coronado, Dr. Fernanda Duarte and Dr. Greg Teal.
} 
The phrase 'culture of corruption,' according to Morris (2000: 227, note 16), was first used in the corruption literature by Le Vine in 1975. In Mexico it now has wide currency, in ordinary conversations, in newspapers (e.g. La Jornada 10/02/2002) and official documents (e.g. Escobar 2004), to refer to a complex problem that Mexico must solve before she can participate fully in the global economy. The connotations of corruption as culture, along with other metaphors, such as the 'cancer of corruption, ${ }^{3}$ exert a powerful influence on the way corruption is understood, and anti-corruption efforts are designed (for the impact of metaphoric language see Morgan 1998).

A common definition of corruption applied by monitoring organisations to measure 'the extent of corruption' is 'the misuse of public power for private benefit' (Lambsdorff 2004: 3). Such a broad definition is, however, too reductive and misses important distinctions needed to understand the problem and do something about it. When measuring and trying to reduce the 'extent of corruption' it is misleading to ignore distinctions between practices treated as equal under such a general understanding of corruption. ${ }^{4}$ Is it the same to fight against 'petty corruption' as 'grand corruption'? Is the same strategy needed to combat bribes in the conduct of public services as to obtain multimillion-dollar contracts? Is it the same to ask for a favour to get a job when you are unemployed as to ignore drug trafficking or white collar fraud? Obviously not.

Rule-breaking happens in every society but there are many ways of judging the actions and their impacts. Different forms of breaching the social order are given different legal or moral weight depending on the outcomes, the power and status of rule-breakers and beneficiaries, and the cultural values of the country or organization in which they happen. Depending on cultural, social, economic, ideological and political factors, similar practices in different situations (e.g. public or private, formal or informal), or in different countries, (e.g. developed vs. developing), might be labelled acceptable or unacceptable, as demonstrating creativity and flexibility or as corruption. To judge such practices sometimes as corruption and sometimes not involves intercultural ideological forms, historically constructed in the complex global dynamics of international relations as postcolonial ideologies (see During 2000). Said (1978) has shown that representing

\footnotetext{
${ }^{3}$ This metaphor is used among others by James Wolfensohn, president of the World Bank in 1996 (in Seligson 2002: 410, note 6)

${ }^{4}$ For broader perspectives on corruption in different contexts and countries see: Heidenheimer, Johnston and LeVine 1989; Rose-Akerena 1999; Morris 1991; Valverde n.d.
} 
the world in these terms is a strategy, 'Orientalism,' by which colonial powers (mis)represent the 'other' from the perspective of the dominant westerner as a means of domination. Based on economic and political dominance some nations consider their cultures as inherently superior, and those who are different as inferior.

Postcolonial ideologies have influenced global representations of countries and cultures in the context of global markets, and are implicit in discourses of managerialism (see Chiapelo \& Fairclaugh 2002), which have become hegemonic among business organisations and beyond, shaping the way governments construct political discourses (Hodge \& Coronado 2006). The managerial discourse impacts on the way countries interact with each other in the context of globalization, culturally, politically and for trade (Spich 1995). As such it can be considered a discursive regime (Foucault 1971), in which privileged speakers reinforce through their language the interests of the dominant.

Framed by this hegemonic discourse, international bodies, mostly led by developed nations, represent and measure corruption globally, considering it a risk, another cultural obstacle, for developing countries wishing to integrate into the global economy, inhibiting Multinationals from doing business with them. Corruption is perceived as a 'country risk,' affecting their level of 'attractiveness.' According to the findings of the World Business Environment Survey, country scores in corruption indexes are important considerations for investment decisions (Bartra et al. 2003), a key factor in the international business environment to differentiate nations in terms of competitive advantage (Porter 2001). To be competitive in gaining access to foreign investment, a country needs to look attractive in the eyes of potential investors, as attractive as any other 'commodity' offered in the marketplace (Kotler et al. 1993). Consequently, countries need to eradicate corruption or at least show they are trying.

In this context, the assumption that corruption is part of the culture conveys the sense that countries rated with high risk have a behaviour deeply rooted in their collective consciousness, that everyone shares the values associated with such cultural behaviour, and acts on them in their everyday practices. In this view it is not an anomaly produced by individuals acting against the social order but the effect of the common values of the whole society, passed on across many generations, naturalised as acceptable to all members and highly resistant to change. From the perspective of the people whose 
'culture' is under judgement, this reinforces the sense of collective undervaluation in postcolonialism. It is also useful for some who benefit from denouncing or not rejecting practices that are actually not aspects of the national culture but rather institutionalised conditions under which they seek profits in the Neoliberal political economy. The metaphor 'culture of corruption' displaces the problem and obscures ways of dealing with it, thus ignoring other areas that in fact lead to corruption in its worst forms, benefiting corrupt, self-serving governments and elites, and not the people.

Representing corruption as part of the culture works well to benefit transnational sectors wanting to do business in 'developing' countries. If corruption is seen as part of the 'host' culture, and 'experts' on intercultural business relations advise them to be culturally sensitive and respect the culture of the 'other' and act accordingly, even though they claim to know are wrong (see Westwood 2006), then business should follow those practices. In this way postcolonial assumptions about culture serve to justify many acts of corruption carried out in the name of cultural sensitivity. The management of intercultural issues in the expansion into other markets has been influenced by the ideas of Hofstede (2001 [1980]), whose understanding of national cultures was based on a survey applied in one organisation, IBM. His study focused on what can be considered in a broad sense 'organisational culture,' the way of doing things in an organisation (for an overview of different understandings of organisational culture see Alvesson 1993).

The data he collected indicated how employees in different countries report behaviours, attitudes and preferences in the workplace in different nations. That data was interpreted, classified and ranked, producing characterisations that were generalised as if representative of the whole national culture. An analysis of his interpretations of cultures reveals an implicit dichotomy, in which the Anglo/protestant/western behaviour, 'our way,' is naturalised as the 'right' behaviour, while alternative practices from other nations, the 'other's way,' are implicitly assumed to be wrong: inefficient and immoral (see Fougere and Moulettes forthcoming).

Generic attitudes, which Hofstede calls ‘dimensions of culture’_-'high/low powerdistance,' 'individualism-collectivism,' 'high/low uncertainty avoidance' 'masculinityfemininity'-were applied to classify cultures in asymmetrical binaries. One kind of 
behaviour is associated with negative outcomes for business and its opposite with positive ones. From an Anglo business perspective the characteristics of the 'other,' usually the developing countries, become by definition negative behaviours, deterministically reproduced by their culture and judged indiscriminately as a problem for business operations. Such ideological interpretation of behaviours related with the cultural dimensions are defined as natural to the 'culture' of these nations and the source of their problems (for example, in a collectivist society the use of friends and family networks), or highly regarded for those ranking high in power distance structures. Following this influential perspective the culture of the 'other' is assumed to be an obstacle that corporations need to 'tolerate' and deal with to be effective (for business discourses of tolerance as a postcolonial strategy, see Coronado, forthcoming).

To consider corruption as inherent to culture assumes a link between corruption levels in a country and its cultural characteristics. It is important to take culture into account but to do so in such a simplistic way is problematic. Corruption as a complex phenomenon includes some links with cultural practices, in which agents of corruption take advantage of the 'contradictions and ambiguities of the normative system for personal lucre' (Lomnitz 2000, 15 my translation; see also Harrison and Huntington 2001). But that normative system and its cultural practices are not fixed nor limited to a specific nation, but linked to the broader conditions in which economies and political bodies operate inside each nation and interact in the global context (Bull \& Nevel 2003; Elliot 1997). In this light I will evaluate the link between practices associated with corruption and Hofstede’s cultural dimensions.

\section{The Ideological Measurement of Corruption.}

The association between cultural dimensions and corruption was not an aim in Hofstede's work, although the link is made in the business literature, and he explicitly introduced it in recent revisions of his work (Hofstede \& Hofstede 2005). It is easy to correlate cultural dimensions in his terms with practices that are perceived and measured as corruption in the indexes: 'collectivist' cultures can be associated with nepotism and 'individualist' with individual merit; high 'power distance' with abuse of authoritarian power and discretionary power, while low power-distance is claimed to generate fairness. Masculine cultures are associated with machismo, which produces favouritism, discrimination and sexual harassment, whereas feminine cultures promote 
equal opportunity and care for the needy. The link between corruption and uncertainty avoidance, i.e. 'the extent in which members of a culture feel threatened by unknown or ambiguous situations' (Hofstede \& Hofstede 2005: 167) is more ambiguous, since it can be seen as a positive quality in the context of business competitiveness, with flexibility or capacity for innovation; but it also relates to rule orientation, daring to break rules or not, which in itself creates unknown situations. Paradoxically, for Hofstede strong uncertainty avoidance (as in Mexico, 82 in the index) is associated with more perceived corruption (2005: 168 \& 352).

Corruption and innovation both involve 'breaking rules,' but in one case it is assumed to have damaging effects while in the other it is seen as positive for the competitive global market, now recognised as uncertain. To judge the act of breaking rules positively or negatively is problematic, and similar practices are judged differently, depending on the contexts, perceptions of the development-status of the countries, how the behaviours are associated with those national cultures, and views of cultures reflecting postcolonial ideologies. Corruption and inefficiency are commonly seen as inherent characteristics of the culture of 'developing' nations. As such, the place they occupy in the corruption index is unequivocal. They have 'wrong' behaviours according to the cultural dimensions, and therefore are economically underdeveloped and rank high in corruption. All these qualities come neatly together, and naturalize the link in the eyes of international business managers who rely on these ratings as an easy way to make decisions.

Corruption indexes assigned by bodies such as Transparency International (TI), and cultural values connected with 'good management,' become important tools to evaluate a nation's attractiveness (high or low risk). Under this ideology a country judged as corrupt wanting to reform must try to change that perception, reduce its scores and put anti corruption schemes in place, learning from more developed nations how to manage properly.

In order to show similarities between measurement of corruption and countries' cultures I will compare them. Both instruments legitimise their authority with a scientific discursive regime, which promises that their 'truth' has been rigorously obtained. The statistical apparatus allows extrapolation of findings from subjective judgements, 
perceptions, and attitudes, elicited from samples as if they referred to the whole nation. The behaviour of some persons from this sample, which is not even statistically representative in their own terms, becomes 'THE culture/behaviour' of a nation. Perceptions of organisational culture or 'extent of corruption' provided by participants in the sample are ascribed to the society as a whole. Both instruments take the scientific discursive regime seriously, and include explicit statements about the limitations of the instruments, but these are buried in the more technical texts, and then ignored in the use of the measurements by the wider public, non-government organisations, governments, academics and businesses.

Both instruments use the same ideological strategy, which draws on the views and values of business people as if they were the sole legitimate possessors of knowledge about that society. In Hofstede’s study, the 'experts’ on national culture are IBM managers (although it is not clear in all cases whether the managers were nationals or expatriates). In TI, the Index 'reflects the views of business people and analysts around the world, including experts who are residents in the countries evaluated' (Transparency International 2004, 6). As experts they know the 'other' since they live there and do business with them. For a brief illustration Table 1 compares the two instruments, to show elements in common in their postcolonial strategies.

Country classifications based on measurements of cultural dimensions and corruption indexes become guidelines for businesses operating globally, trying to reduce risks. Intentionally or not, the measurements misrepresent whole societies. Their cultures, including their propensity for corruption, are perceived as inadequate, difficult or impossible to change. Imprecise and wildly generalised judgements on countries as more or less corrupt without distinguishing what kind of practices are measured allow whole societies and cultures to be 'blamed,' for practices of specific sectors or individuals that are not always targeted by anti-corruption campaigns.

\section{Fighting Corruption the Mexican way}

To make Mexico 'attractive' the government is meant to control the levels of corruption that have been measured and publicised through Corruption Index, but Neoliberal pressures confront Mexican governments with a paradox: they need to regulate the informal polity and the corruption associated with its practices, and simultaneously 
ignore the fact that it is happening. To penalise the practices of the informal economy without offering an alternative to increasing unemployment and poverty will not stop the problem and might create another country risk, political unrest.

\begin{tabular}{|c|c|c|}
\hline Elements. & $\begin{array}{lll}\text { Hofstede's } & \text { National } & \text { Culture } \\
\text { Dimensions. } & & \end{array}$ & $\begin{array}{l}\text { Transparency International } \\
\text { Lambsdorff's Background Paper to } \\
\text { the } 2004 \text { Corruption Perception } \\
\text { Index. }\end{array}$ \\
\hline $\begin{array}{l}\text { Definitions of concepts } \\
\text { in essential terms that } \\
\text { encompass multiple } \\
\text { practices. }\end{array}$ & $\begin{array}{l}\text { Broad Definition of culture: Based } \\
\text { on few dimensions of organisational } \\
\text { culture, as representing the whole } \\
\text { culture of a society. } \\
\text { 'The software of the mind.' }\end{array}$ & $\begin{array}{l}\text { Broad definition of corruption: } \\
\text { 'Corruption can range from petty } \\
\text { bureaucratic corruption (such as the } \\
\text { paying of bribes to low level officials) } \\
\text { right through to grand political } \\
\text { corruption (such as the paying of large } \\
\text { kick-backs in return for the awarding o } \\
\text { contracts).' }\end{array}$ \\
\hline $\begin{array}{l}\text { Individual perceptions } \\
\text { treated as objective } \\
\text { truths. }\end{array}$ & $\begin{array}{l}\text { Attitudes in the workplace toward } \\
\text { bosses and colleagues are the } \\
\text { nation's behaviour. }\end{array}$ & $\begin{array}{l}\text { Perceptions of 'propensity' to act } \\
\text { corruptly as actual corruption. }\end{array}$ \\
\hline $\begin{array}{l}\text { Culture as homogenous } \\
\text { at national level. }\end{array}$ & $\begin{array}{l}\text { Sample behaviour is considered } \\
\text { homogenous for whole country and } \\
\text { region. }\end{array}$ & $\begin{array}{l}\text { Construction of Country perception } \\
\text { index from the results of a few surveys } \\
\text { not systematically applied. }\end{array}$ \\
\hline $\begin{array}{l}\text { Imprecise terms in the } \\
\text { instruments of } \\
\text { measurement. }\end{array}$ & $\begin{array}{l}\text { Individual 'preference' in the form } \\
\text { of operating inside an organization. }\end{array}$ & $\begin{array}{l}\text { Extent of corruption measured by } \\
\text { imprecise terms: 'prevalence,' } \\
\text { 'commonness' 'frequency,' } \\
\text { 'likelihood,' 'problematic,' 'severity.' }\end{array}$ \\
\hline $\begin{array}{l}\text { Naturalisation of } \\
\text { association between } \\
\text { characteristics and } \\
\text { judgements. }\end{array}$ & $\begin{array}{l}\text { Cultural dimensions of the other } \\
\text { negatively valued, the developed } \\
\text { positively E.g. Collectivism = } \\
\text { corruption vs. Individualism = } \\
\text { democracy. }\end{array}$ & $\begin{array}{l}\text { Business sectors as moral authority to } \\
\text { judge nation's behaviour: perception } \\
\text { from 'senior business people,' 'panel o } \\
\text { experts,' 'elite business people,' 'staff } \\
\text { to a foreign country,' 'expatriate } \\
\text { business men.' }\end{array}$ \\
\hline
\end{tabular}

Table 1: Measurement of culture and corruption in comparison

To deal with this paradox, governmental agencies act inconsistently, sometimes banning some practices, at other times ignoring them. They have also introduced minor changes that reduce the perceived potential of the informal polity to become actual corruption, by regulating a posteriori what is already out of control. One such move was to create designated spaces for illegal street sellers. Another attempt to regulate the unregulated was to reduce the bureaucratic structure involved in delivering services by government agencies, a program called Simplificación administrative (Administrative Simplification). This program attempted to reduce corruption in the interface between the public and the service desk by making some public services free or redirecting payments to the budget office cashier (Tesorería) or into banks. In that way the circulation of money associated with fees (and exposed to bribes) was transferred to public or commercial institutions that have no involvement in the administrative process. 
The impacts of this kind of initiative are difficult to evaluate, but according to peoples’ perceptions (from interviews) to submit and pay for an application does not avoid being asked for a 'tip,' which is generally given with the unspoken fear that otherwise the process will be delayed, or the documents 'lost':

in the entrance there is a giant sign that says: No payment for procedures in this office. Everything to be paid in the tesorería. But when we married, when we have already signed, he told us "Well ... mmh ... whatever you would like to give for the judge's cooperation ..."

Although just anecdotal, this example points to the need to distinguish between culture of corruption for survival and institutionalised corruption, another phrase used to refer to the problem of corruption in countries with high corruption indexes. Institutionalised corruption is an outcome of complex historical, political and economic conditions that shaped how governments and economic elites have functioned in the country, from early colonial times till the globalised present (See Semo 2000). It refers to the conditions under which citizens and organisations interact with public bureaucracies, within a legal framework that in Mexico is seen as undemocratic, inefficient, discretional and insecure (del Castillo \& Guerrero 2003). The distinction is useful given the impacts that simplistic views of the phenomena have on the success or failure of anti-corruption initiatives. The two phrases point to different understandings of the phenomena and how to fight against it.

To illustrate the postcolonial ideology in the discourses that have emerged out of global pressures (from finance institutions, corporations and global organisations) to control corruption levels in Mexico I will analyse two examples I found during my research in Mexico City, in April-May 2006. The examples come from different initiatives that self represent as against the 'culture of corruption,' promoting the 'culture of legality.' One is a May 2006 press release from Transparencia Mexicana (TM), the Mexican chapter of Transparency International. The second is a billboard from the Consejo de la Comunicación AC (Council of Communication, Civil Association), a business organisation that calls itself La voz de las empresas (the voice of business).

\footnotetext{
${ }^{5}$ All translations of Spanish are mine: 'en la entrada dice un letrero gigante: en esta oficina, ningún trámite tiene costo. Todo lo tienes que pagar en la- tesorería pero cuando nos casamos, ya que firmamos no sé qué, nos dijo "Bueno ... pues .... este ... lo que gusten cooperar para la juez”، (Interviewee 06/05/2006)
} 


\section{Transparency Mexican’s public voice}

Transparency Mexican is the 'author' of the document I analyse. Its self-description appears at the bottom of the page by way of a signature:

Non-government organisation which combats corruption in Mexico from an integrated perspective, through public policies and private attitudes which go beyond policy pronouncements to generate concrete changes in the institutional framework and the culture of legality. ${ }^{6}$

In order to communicate to the public through the media this organisation released a synthesis of the last results of the application of the Índice Nacional de Corrupción y Buen Gobierno (National Index of Corruption and Good Governance in Mexico). Table 2 includes some elements from the document that highlight the ideological construction of corruption in this text.

\begin{tabular}{|l|l|l|}
\hline & My translation & Quotes in Spanish \\
\hline Title: & $\begin{array}{l}\text { Mexico, stuck in its corruption levels: } \\
\text { Transparency Mexican. }\end{array}$ & $\begin{array}{l}\text { 'México, estancado en sus niveles de } \\
\text { corrupción: Transparencia Mexicana.' }\end{array}$ \\
\hline $\begin{array}{l}\text { Name of } \\
\text { Instrument: }\end{array}$ & $\begin{array}{l}\text { National Index of Corruption and } \\
\text { Good Government. }\end{array}$ & $\begin{array}{l}\text { 'Índice Nacional de Corrupción y Buen } \\
\text { Gobierno.' }\end{array}$ \\
\hline Scope: & $\begin{array}{l}\text { In } 3 \text { levels of government and private } \\
\text { business. }\end{array}$ & $\begin{array}{l}\text { 'en 3 niveles de gobierno y empresas } \\
\text { particulares.' }\end{array}$ \\
\hline What was & $\begin{array}{l}\text { Payment of bribe or 'mordida,' which } \\
\text { measured: }\end{array}$ & $\begin{array}{l}\text { 'Pago de soborno o 'mordida' declarado por los } \\
\text { hogares mexicanos.' }\end{array}$ \\
\hline Agents & $\begin{array}{l}\text { Mexico. } \\
\text { Federal entities/states. } \\
\text { Households. } \\
\text { Households ...headed by youngsters, } \\
\text { as well as those with higher } \\
\text { educational levels. }\end{array}$ & $\begin{array}{l}\text { 'México.' 'entidades federativas/estados.' } \\
\text { 'hogares.' } \\
\text { 'hogares...encabezados por jóvenes, así como } \\
\text { aquellos que tienen mayores niveles educativos.' }\end{array}$ \\
\hline Results: & $\begin{array}{l}\text { Fouseholds inclined to pay bribes. } \\
\text { headed by young people, as well as } \\
\text { those who have the highest education } \\
\text { levels, continue to be more inclined to } \\
\text { participate in acts of corruption. }\end{array}$ & $\begin{array}{l}\text { 'Propensión de lo hogares a pagar sobornos' } \\
\text { 'De los hogares del país, los encabezados por } \\
\text { jóvenes, así como aquellos que tienen mayores } \\
\text { niveles educativos siguen siendo los más } \\
\text { propensos a participar en actos de corrupción.' }\end{array}$ \\
\hline
\end{tabular}

Table 2: Elements of the press release from Transparency Mexican.

One press release from Transparencia Mexicana is too little to prove much. However, when analysed closely it throws up relevant meanings for my argument. First, the title produces a shock in the audience (myself, in the first instance). Through its links with Transparency International the speaker, TM, establishes its expert status to evaluate corruption in Mexico. From that position it declares that Mexico is 'stuck in' levels of corruption, which suggests that everything done so far has failed. The reader learns later

\footnotetext{
${ }^{6}$ For original in Spanish see full document in Appendix at the end.
} 
in the text that in fact this is not so, that there have been improvements in some sectors and that actually 'Half the number of the country's federal entities reduced the occurrence of corruption' in some services. The text mentions fluctuations in different years, a reduction from 2001 to 2003, increasing in 2005 but still lower than in 2001. Even though the information provided in the document paints a more complex picture, the simplistic title conveys a sense of failure that implies the difficulties of changing a culture of corruption into a culture of legality, the aim of this organisation as presented at the end of the press release. In this reading, the text creates a sense that small outcomes are insufficient to fulfil the grand aim of this organisation: to transform Mexico’s culture of corruption into a 'culture of legality.'

From other sources we find that the comparison is inexact, since the data does not come from a longitudinal study but from different samples. It is unclear if the differences cited showed that the various groups are more honest in reporting bribes, or if the actual corruption in the delivery of services has changed. Detailed information about the instrument is available in the organisation web page (http://www.tm.org.mx) but to the public, the press release and article arouse the maximum concern.

The grammatical subjects of the different sentences in the text produce confusion. It is difficult to know who the agent of corruption is, and who is trying to improve. Mexico is a problematic subject of the sentence in the title. If it is subject, Mexico is the agent of corruption, illustrating the postcolonial strategy in which an evaluation based on a sample of individual perceptions is generalised to construct an image of the whole nation as responsible for the success or failure of the action. If Mexico is the agent, then what is the role of the entidades federativas (states of the federation) that the same document says are reducing the incidence of corruption? In those cases they are not agents of corruption, but agents who reduce corruption. How is it possible that the whole is the agent of corruption, and the parts are those who try to reduce it?

There is another ambiguity in the name of the instrument. What exactly is the index measuring? Corruption? Or good government? Does it imply that those are opposites, so that reducing corruption means good government? In Spanish the use of the word gobierno creates the sense that the problem is mostly associated with government offices, so that private businesses (even if mentioned as providers of some of the 
services evaluated) are made invisible. The document does not mention which services are public and which are private. This imprecision shifts the focus onto the practices of common people, those who reported bribes, not those who demand them and are the real targets of the Index: those in charge of trámites (administrative procedures) or who provide servicios públicos (public services). The document is also imprecise about its scope, implying that the Index registers the payments of all bribes declared, as if its scope were universal when actually the index is based on a sample and not all those surveyed may have reported honestly.

There is another agent of corruption included in the text. According to the document the Index registers the payment of bribes, mordidas, declared by hogares. The word can be translated as household but its literal translation is 'homes.' Hogares has emotional connotations that connect with family life, the intimate space in which individuals are socialised. This tacitly reinforces the idea that corruption comes from the culture: by stating that 'homes' 'declared' they paid bribes, it implies that 'homes' are the agents in these acts of corruption, ergo, it is a cultural practice. If 'Mexican homes' are 'inclined to’ pay bribes, as stated in the text, does it mean that members of a family home are all inclined to be corrupted, thus condemning the culture to continue without change?

The presentation of the outcomes continues this ambiguity. One phrase emphasises the home's inclination to be involved in acts of corruption: 'The results raise an alert about homes' inclination to pay bribes.' From this and other similar phrases used in the document we are led to suppose that all members of the family are corrupt, thus increasing the number of people supposedly included in the sample, justifying the generalisation to the whole of Mexico. In another document from the same organisation the mathematical basis is explained: a sample of '14,019 homes with between 383 and 514 households surveyed in each federal region' is then 'extrapolated to the whole population' where 'the results imply almost 101 million acts of corruption in the 38 services during the year' (Transparencia Mexicana 2005). In a country of 103.3 million (according to the 2005 Census, INEGI 2005) if this is treated as an average this 'extrapolation' makes it seem that each citizen (except for 2.2\% honest Mexicans) committed a corrupt act that year.

In another part of the press release TM focused on one kind of 'home' especially 
'inclined' to be corrupt: young and educated. Interestingly, in this case the term used is soborno instead of mordida. Both terms in this context would be translated by the same English word, bribery, but the text distinguishes between the two, 'soborno o mordida.' The difference is the gravity of the 'crime.' The term mordida is part of the Mexican 'folklore of corruption' (Covarrubias 2003) linked in the text with 'petty corruption,' which 'affects the income of Mexican homes': mostly those with less than the minimum income (in 24\% of cases, the text informs us). By comparison the young and educated 'homes,' not in the lowest income sector, are constructed as involved in more serious corruption, paying sobornos.

The text does not offer readers an explanation of this behaviour, letting them form their own conclusions. One reason for the figures is that these youngsters may be more ready to report bribes. In one of my interviews with a family of 3 women of different generations the youngest criticised her mother for denying that she has used informal practices (favores) to help her to solve problems. Other possibilities are that this sector is frustrated to be unemployed or poorly paid after long years of study and investment in education, or that they refuse to waste their time in tedious bureaucracy when they are paid more than the cost of bribes paid to low-wage employees. The young people's ‘inclination' to pay bribes, whether it reflects frustration, cynicism or lower moral values, challenges the postcolonialist assumption that corruption is higher in less developed countries because of their cultural backwardness. If we suppose that the young and educated are more influenced by other cultures, in Mexico this means adopting 'the American way,' omnipresent in Mexican media and life (Coronado \& Hodge 2004), how does their propensity come from supposedly corrupt and backward Mexican culture?

It is also plausible, although difficult to demonstrate without more extensive research, that their attitudes can be linked to changes of social expectations and values influenced by their exposure to Neoliberal and postcolonial ideologies, which have failed to deliver. Under a global economy the promise that individual success and higher consumer capacity will bring economic development, higher employment and social prosperity is only fulfilled for the few who, according to the dominant discourse, are developed, have the right cultural qualities and therefore inhabit a culture of legality. For the rest, Neoliberalism and Postcolonialism not only fail to transform the economic, social and 
political conditions in which corruption is played out, but through this failure help reproduce the institutionalised corruption that produces winners and losers in both developed and developing worlds.

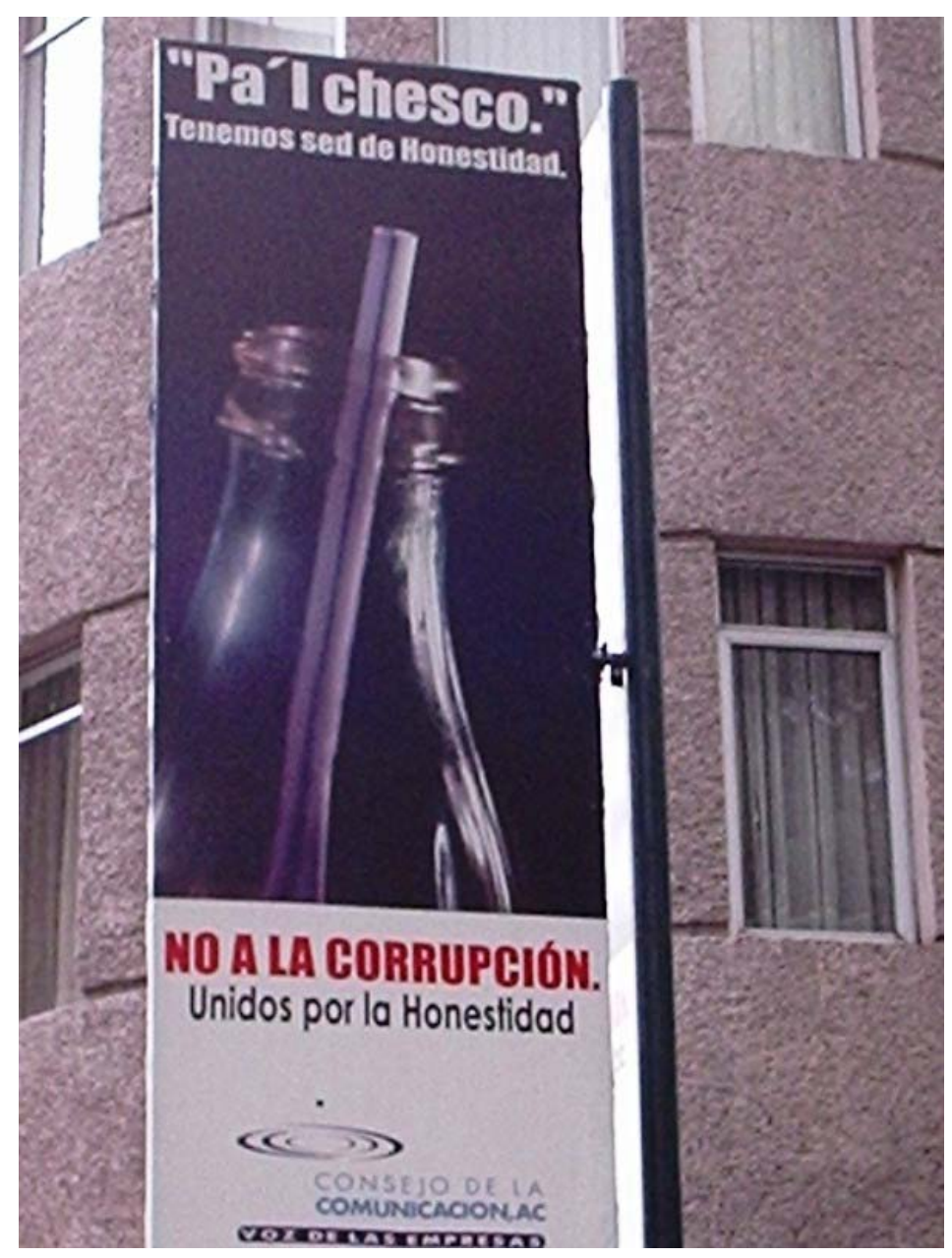

Image 1: Billboard in the streets of Polanco, Mexico City (C Author)

The Voice of Mexican Business

When I was driving in Mexico City in May 2006 in a wealthy neighbourhood, Polanco, a street billboard caught my attention. At first I did not realised that it was an anticorruption campaign by business organisations. I passed it many times, and only when I was able to read all parts of the text and image did I appreciate its relevance for my research. Then I stopped to take a picture (See image 1).

My initial puzzlement came from the fact that the image and the related text that dominates it, $\mathrm{Pa}$ 'l chesco, refers to a popular phrase that means 'for a fizzy drink.' This meaning is reinforced by the image of a bottle with a straw. Even though in some cases 
asking for a soft drink might be a euphemism for demanding a bribe, ${ }^{7}$ the language used in the poster is mostly associated with low income workers providing a service. The expression usually comes as a polite request: Señito, ahi pa'l chesco, $\dot{\complement}$ no? (Dear Madam, something for a fizzy drink, no?). Literally it is a request for something to buy a cool drink after hard work under the sun. I have heard it all my life, when someone has provided me with a service; from people who serve petrol in a garage station who do not receive a salary, from macheteros (men that carry building products) delivering bags of cement or bricks to your house, known to earn low wages, and also from employees of big companies who deliver products, and are probably earning the minimum salary. I did not see a similar campaign in other less affluent neighbourhoods. Why was it run there? Was it directed to wealthy people, recommending them not to give tips? Or was it trying to compensate for the bad image of business from international scandals such as Enron?

At first glance we might suppose that the people running this campaign are familiar with the language and culture of ordinary people who use this phrase, and sympathetic to their needs. But by linking the phrase in the top with the next line 'we are thirsty for honesty' (and other phrases below) the text constructs an opposition. It implies that one action, workers asking for a soft drink, is the problem that needs to be solved, to fulfil the wish of business for honesty. At the foot of the image the speaker is identified as the Council of Communication A.C. (Civil Association), who declare that they are the voice of business. Above this 'signature' is an image of a falling drop of water, creating ripples. This image implies that this small contribution from business, the billboard, will expand and produce the change needed to satisfy their desire. The question is how this phrase used by common workers plays a part in the campaign, as against the business leaders' 'thirst for honesty'? The two phrases polarise two sectors. Business are thirsty for honesty and do not use that language (implying they are not corrupt) while common people are literally thirsty and cannot buy a soft drink but are to blame for corruption, like the 'homes' the TM press release identified as having inclinations to be corrupt.

Below the image the statement 'NO A LA CORRUPCIÓN' (Say no to corruption) indicates that the main voice in the text is that of people united in honesty to reject

\footnotetext{
${ }^{7}$ As in an example reported by del Castillo and Guerrero: 'si quieres con el refresco nos arreglamos' (if you want with a soft drink we can fix it) (2003: 21).
} 
corruption. But if corruption in this view is interpreted as demanding a tip, what actions would oppose it? To impose a new rule that low-paid employees are not allowed to ask for a tip? Or maybe, if we believe in the good will of businesses (at least those united against corruption) they will increase wages so that workers do not need to ask pa'l chesco? A sceptic will suspect that they will just continue with their campaign as 'ethically responsible businesses,' saving some taxes for this contribution to society, building a positive image, and maybe, still profiting from institutionalised corruption.

\section{Concluding Remarks}

Through analysing these two examples I draw attention to the weight given in anticorruption initiatives to practices from the informal polity, mostly associated with poorer sectors of society. These practices are not so much a culture of corruption as basic to survival. From this we can see that to represent corruption as inherent in a culture targets informal practices used by common people to survive, instead of focusing on the contexts of institutionalised corruption, which involve national and global agents pressuring developing countries to become cheap open markets, with the reduced welfare required by Neoliberal models as conditions for aid or loans.

The so-called culture of corruption has attributed the 'problem' to culturally learned behaviours of common people, who supposedly act in that way in any context, whether as citizens or on behalf of private or public organisations. Corruption in this view is linked to the country's 'cultural dimensions,' which according to the postcolonial managerial discourse prevent the country from perform efficiently in the global economy. According to this ideology, stopping corruption means changing the behaviour of common people, 'the family homes that are inclined to corruption.'

The analysis of anti-corruption initiatives shows their focus on behaviour at lower levels of bureaucracy and in the 'homes' that interact with them, not exposing systemic practices that owe much to global pressures in the contemporary Neoliberal dispensation. Ordinary Mexicans have internalised discourses that characterise their practices as a 'culture of corruption.' But these practices, irrespective of whether they are called culture, folklore, cancer, creativity, flexibility or corruption, seem their only way to deal with a state bureaucracy economically and politically complicit with the interests of the Neoliberal global economy. 
The examples analysed from Transparencia Mexicana and La Voz de las empresas show that these bodies, intentionally or unintentionally, respond to those interests and perspectives, promoting an image in which common people acting a la mexicana are to blame for the poor image that makes Mexico unattractive and uncompetitive. In that context, discourses of transparencia (transparency), moralización (moralisation) honestidad (honesty) or buen gobierno (good governance), adopted by governments, politicians and business groups to fight this soft target, appear as just rhetoric, and probably do not really aim to change Mexico for the benefit of its peoples. 


\section{Appendix one}

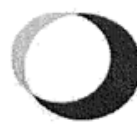

\section{TRANSPARENCIA MEXICANA}

\section{Comunicado de Prensa \\ 9 de mayo de 2006}

\section{México, estancado en sus niveles de corrupción: Transparencia Mexicana}

- El Índice Nacional de Corrupción y Buen Gobierno pasó de 10.6 en 2001 a 8.5 en 2003 y a 10.1 en 2005.

- El Índice detectó una incidencia mayor en los 35 servicios públicos considerados por el estudio. De los 35 servicios, 11 mejoraron su indice respecto a la medición realizada en 2003.

- La mitad de las entidades federativas del país redujo la incidencia de corrupción en esos servicios respecto a 2003.

- Guerrero, Hidalgo, Tabasco, Estado de México y Distrito Federal, las entidades con la mayor incidencia de corrupción en servicios públicos. Querétaro, Chiapas, Baja California Sur, Sonora y Guanajuato, las entidades con la menor incidencia de corrupción en el pais.

Ciudad de México, 9 de mayo de 2006.- Esta mañana, la organización no gubernamental Transparencia Mexicana publicó los resultados del Índice Nacional de Corrupción y Buen Gobierno 2005. El Índice Nacional de Corrupción y Buen Gobierno (INCBG) es un instrumento que registra los pagos de "mordidas" declarados por los hogares mexicanos en 35 servicios públicos provistos por los tres niveles de gobierno y empresas particulares.

EI INCBG 2005 registró un incremento respecto a 2003, pasando de 8.5 a 10.1 puntos en 2005. El INCBG se ubica así en niveles comparables a los de 2001, cuando alcanzó una frecuencia de 10.6 puntos.

EI INCBG registra el número de veces en que se pagó un soborno o "mordida" por cada 100 veces que se realizó un trámite o se obtuvo un servicio público. Por ello, si el índice aumenta ello significa que la incidencia de corrupción en un trámite o servicio se incrementó. Por el contrario, un índice menor refleja una frecuencia más baja de soborno en ese trámite o servicio. En conferencia de prensa, Federico Reyes Heroles, presidente del Consejo Rector de Transparencia Mexicana, destacó un incremento en los niveles de corrupción entre 2003 y 2005. "El Indice Nacional de Corrupción y Buen Gobierno, enfatizó Reyes Heroles, es un instrumento sensible a las acciones de política pública de los gobiernos. EI INCBG registra si una estrategia anticorrupción es consistente en el tiempo, o si un gobierno o agencia gubernamental, para decirlo claramente, bajó la guardia".

Con relación a 2003, el INCBG 2005 registró 16 entidades que redujeron su incidencia de corrupción, pero ello Con relación a 2003, el INCBG 2005 regición del INCBG, no fue suficiente para mantener el ritmo de reducción respecto a 2001. En Guerrero, Hidalgo, Tabasco, Estado de México y Distrito Federal, fueron las entidades con la mayor incidencia de corrupción en servicios públicos, mientras que Querétaro, Chiapas, Baja California Sur, Sonora y Guanajuato
fueron los estados con menor incidencia de corrupción en el pais.

EI INCBG 2005 confirma la tendencia registrada en las ediciones 2001 y 2003 en el sentido de identificar a la EI Corrupción en servicios públicos como un impures a un salario mínimo, el costo de la llamada "pequeña corrupción" alcanzó el $24 \%$ de sus ingresos.

Los resultados publicados esta mañana alertan también sobre la propensión de los hogares a pagar sobornos. De los hogares del país, los encabezados por jóvenes, así como aquellos que tienen mayores niveles educativos, siguen siendo los más propensos a participar en actos de corrupción.

Transparencia Mexicana, A.C. es una organización no gubernamental que enfrenta la corrupción en México desde una perspectiva integral, a través de politicas públicas y actitudes privadas que van más allá de la consigna politica, para genera cambios concretos en el marco institucional y en la cultura de la legalidad en México. Fundada en 1999, es el Capitulo México de Transparencia Internacional, la coalición global contra la corrupción. Los miembros del Consejo Rector, el Presidente del Consejo Rector y el Presidente Ejecutivo contribuyen voluntariamente al trabajo de la organización. www.tm.org.mx

Contacto para los medios:

52.55.5659.4714 extensión 16

Correo electrónico: mdelcampo@tm.org.mx 


\section{Reference List}

Alvesson, M. 1993, Cultural Perspectives on Organizations. Cambridge University Press, New York.

Bartra, G., Kaufmann, D., and Stone A.H.W. 2003, World Business Environment Survey Findings. World Bank Publications, Washington, D.C.

Bull, M.J. and Nevel, J.L. (eds.), 2003, Corruption in Contemporary Politics, Palgrave Macmillan, New York.

Chiapelo, E. and Fairclough , N. 2002, 'Understanding The New Management Ideology: A Transdisciplinary Contribution from Critical Discourse Analysis and New Sociology of Capitalism,' Discourse \& Society, vol. 13, no. 2, 185-208.

Coronado, G. (forthcoming), 'Constructing the "Postcolonial” Manager. Orientalising Latin America in the Textbooks’ in Prasad, A (ed.), Against the Grain: Advances in Postcolonial Organization

Studies. Organization Studies Series, Liber \& Copenhagen Business School Press, Copenhagen.

Covarrubias González, I. 2003, 'El impacto de la corrupción en el proceso de democratización de México. Una propuesta de análisis,' Revista Probidad, vol. 24, 1-14.

Davis, J.H. and Ruhe, J.A. 2003, 'Perceptions of Country Corruption. Antecedents and Outcomes,' Journal of Business Ethics, vol. 43, no. 4, 275-88

Del Castillo, A. and Guerrero, M.A. 2003, Percepciones de la corrupción en la ciudad de México. Online, Available: http://presupuestoygastopublico.org/documentos/transparencia/DT_134.pdf. (Accessed 23 Jan. 2007).

During, S. 2000, 'Postcolonialism and Globalization: Towards a Historicization of Their Inter-relation,' Cultural Studies, vol. 14, no. 3/4, 385-404.

Elliot, K.A. 1997, Corruption and the Global Economy. Institute for International Economics, Washington, D.C.

Escobar, R.E. 2004, 'Corrupción en México: Mal o vicio de muchos,’ Foro: Presidencia de la República, 10 abril. Online, Available: http://foros.fox.presidencia.gob.mx/read.php?13,163892 (accessed 13 Feb. 2007).

Foucault, M. 1971, 'Orders of Discourse' Social Science Information, vol.10, no. 2, 7-30.

Fougere, M. and Moulettes, A. forthcoming, 'Cross-Cultural Management Discourse - Ideas of Democracy, Development, Modernity and Progress in Hofstede’s Culture’s Consequences,’ Prasad, A (ed.), Against the Grain: Advances in Postcolonial Organization Studies. Organization Studies Series, Liber \& Copenhagen Business School Press.

Harrison L.E and Huntington, S.P. (eds.) 2000, Culture Matters: How Values Shape Human Progress. Basic Books, New York.

Heidenheimer, A., Johnston, M., and LeVine, V.T. (eds.) 1989 Political Corruption: A Handbook. Transaction Books, New Jersey.

Hodge, B., and Coronado, G. 2006, 'Mexico Inc? Discourse Analysis and the Triumph of Managerialism,' Organization, vol. 16, no.4, 529-47.

Hofstede, G. 2001[1980], Culture's Consequences: International Differences in Work Related Values. $2^{\text {nd }}$ ed. Sage, Beverly Hills, CA.

Hofstede, G. and Hofstede, G.J. 2005, Cultures and Organizations. Software of the Mind. McGraw Hill, New York.

INEGI 2005, Resultados definitivos del II conteo de población y vivienda para el Estado de Chiapas. México: Instituto Nacional de Estadística Geografía e Informática. Online, Available: http://www.inegi.gov.mx (accessed 5 Feb 2007).

Kotler, P., Haider, D., and Rein, I. 1993, Marketing Places. The Free Press, New York.

La Jornada 2002, 'Podrían seguir en la inercia de la cultura de la corrupción, señala Bravo Mena,' 10 Feb. Online, Available: http://www.jornada.unam.mx/2002/02/10/008n1pol.php (Accessed 13/02/2007).

Lambsdorff, J.G. 2004, Framework Document: Background Paper to the 2004 Corruption Perception Index. 2004. Transparency International and University of Passau, Online, Available: http://www.ICGG.org?downoloads/2004_CPI_FD.pdf. (Accessed 14 August 2005).

Lomnitz, C. (coord.) 2000, Vicios públicos, virtudes privadas. La corrupción en México. CIESAS/Porrúa, México D.F.

Morgan, G. 1998, Images of Organization. Sage, Thousand Oaks, CA.

Morris, S. 1991, Corruption and Politics in Contemporary Mexico. University of Alabama Press, Tuscalosa.

Morris, S. 2000, ‘`"La política acostumbrada” o “política insólita”? El problema de la corrupción en el México contemporáneo,’ in Vicios públicos, virtudes privadas. La corrupción en México. Lomnitz, C. (coord.), CIESAS/Porrúa, Mexico City, 221-237.

Porter, M. 2001 [1990], The Competitive Advantage of Nations. Free Press, New York. 
Robinson, M. (ed) 1998, Corruption and Development. Routledge, New York

Rose-Akerena, S. 1999, Corruption and Government. Causes, Consequences, and Reform. Cambridge University Press, Cambridge.

Said, E. 1978, Orientalism. Penguin, Harmondsworth.

Seligson, M. 2002, 'The Impact of Corruption on Regime Legitimacy: A Comparative Study of Four Latin American Countries,' The Journal of Politics, vol. 64, no. 2, 408-433.

Semo, E. 2000, 'De la colonia a la independencia: la línea imaginaria entre lo público y lo privado contemporáneo,' in Vicios públicos, virtudes privadas. La corrupción en México. Lomnitz C. (coord.), CIESAS/Porrúa, Mexico City, 65-85.

Spich, R. 1995, 'Globalization Folklore: Problems of Myth and Ideology in the Discourse on Globalization,' Journal of Organizational Change Management, vol. 8, no. 4, 6-29

Theobald, R. 1990, Corruption, Development and Underdevelopment. Duke University Press, Durham.

Transparencia Mexicana 2005, 'Measuring Corruption in Public Service Delivery: The Experience of Mexico.' Online, Available:

http://www.globalcorruptionreport.org.gcr2005/download/English/corruption_in_practice.pdf (accessed 14 Aug 2005).

Transparency International 2004, Transparency International Corruption Perception Index 2004, pp. 1-8, Online, Available: http//www.transparency.org (Accessed: 14 August 2005).

Valverde Loya, M.A. n/d, 'La corrupción en México y el entorno Internacional.' Juripolis Online. Online, Available: http://www.ccm.itesm.mx/dhes/juripolis/archivos/avalverde (Accessed 25 Jan. 2007).

Westwood, R. 2006, 'International Business and Management Studies as an Orientalist Discourse: A Postcolonial Critique,' Critical Perspectives on International Business, vol. 2, no. 2, 91-113.

Woodward, D. 2005, Australia Unsettled. The Legacy of 'Neo-liberalism.' Pearson, Frenchs Forest, Sydney. 